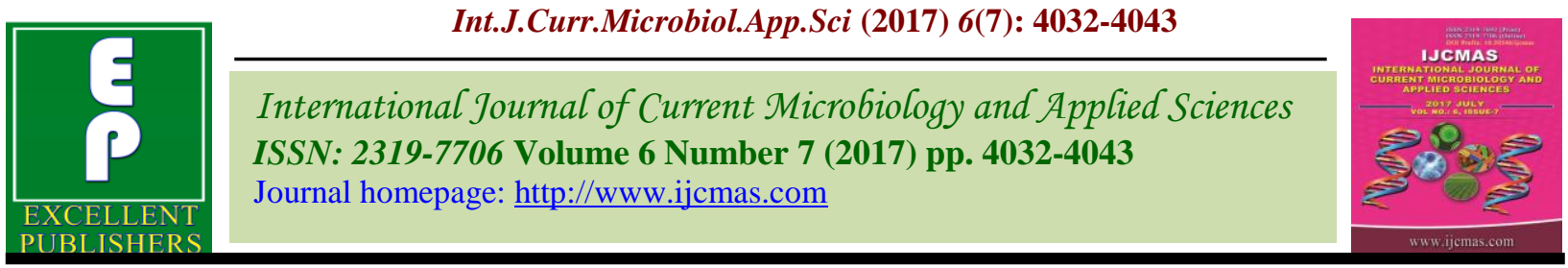

Review Article

https://doi.org/10.20546/ijcmas.2017.607.418

\title{
A Review on Crop Regulation in Fruit Crops
}

\author{
Narayan Lal $^{1 *}$, Nisha Sahu ${ }^{2}$, E.S. Marboh ${ }^{1}$, A.K. Gupta ${ }^{1}$ and R.K. Patel ${ }^{1}$ \\ ${ }^{1}$ ICAR-NRC on Litchi, Muzaffarpur, Bihar, India \\ ${ }^{2}$ Division of RSA, ICAR-NBSSLUP, Nagpur, MH, India \\ *Corresponding author
}

\section{Keywords \\ Crop regulation, Bahar treatment, Flowering, Yield and Quality. \\ Article Info \\ Accepted: \\ 29 June 2017 \\ Available Online: \\ 10 July 2017}

\section{A B S T R A C T}

India is second largest producer of fruits in the world after china. India is rich in fruit diversity starting from tropical, subtropical to temperate region. Some of the fruits like Guava, pomegranate, lemon, mandarin etc., if left without any treatment, give several light harvests of the variable quantities and qualities from the various flowering flushes throughout the year. There are three distinct flowering season i.e. February-March (AmbeBahar), June-July (MrigBahar) and October-November (HasthBahar) with the corresponding harvest period during rainy, winter and spring season, respectively. A good quality production can be ensured by regulating the crop in such a way that they could produce only one crop instead of two or three in a year. Plants are forced to produce only one crop instead of two or three crops with good quality production. The main objective of crop regulation is to force the tree for rest and produce profuse blossom and fruits during any one of the two or three flushes. It can be achieved through with holing irrigation water, root exposure, root and shoot pruning, deblossming, spray of chemical and other plant growth regulators. The selection of bahar at a location is mainly determined by prevailing production constraints like availability of the irrigation water, quality production, and occurrence and extend of the damage by the disease and pests and several market factors. Crop regulation planning is about identifying, selecting, implementing and monitoring methods to control the yield and quality of horticultural crops. To be sustainable, this must be achieved without negatively impacting people, the environment or the financial bottom line.

\section{Introduction}

Some of the fruit crops bloom throughout the year without any resting period and produces two or three crops (bahar) in a year but yield and quality is not so good in all crop harvest. It is very essential to understand the flowering and fruiting behavior of crops and which bahar will give good crop with considering all the factors associated with a particular bahar. The acid limes bloom throughout the year but the main blooming period is February March, with lean period from July to August. It is not uncommon to find, particularly in lime, flowers fruitlets, developing fruits and mature fruits all at a given time (Rajput and Babu, 1985). Mahalle et al., (2010) reported in Hasta bahar flowering (September and October) of Acid lime, two sprays of cycocel $1000 \mathrm{ppm}$ at an interval of one month before initiation of flowering that is in August and September resulted in maximum yield in terms of number of fruits per tree and weight of fruits per tree and this treatment also improved the fruit quality in respect to juice $\%$, TSS, acidity, ascorbic acid content and 
peel \%. Similarly, guava bears varying amount of fruit throughout the year. Guava bloom thrice in a year: Ambebahar, Mrigbahar and Hasthbahar. In north India, major crop usually ripens from July to midOctober (rainy season). A small distinct crop is produced from November to mid-February (winter season) whereas two flowering seasons have been reported in the climatic condition of Assam (Lal et al., 2013). Though, the quantum of production is high in rainy season (Rathore and Singh, 1974 and Singh et al., 2000), it offers poor quality due to insipid in taste (Singh et al., 1996) and infestation of pest (Rawal and Ullasa, 1988) in comparison to winter season. On the contrary, in winter season quality fruits are produced and fetch high monetary returns (Singh et al., 2000). There is a distinct difference in quality in the fruits produced in different season and winter is considered to be more favourable for quality guava production (Rathore and Singh, 1974; Pandey et al., 1980 and Singh, 1985). Though rainy season crop give higher yield, the fruit is often infested by many pests and diseases (Rawal and Ullasa, 1988) and they are rough, insipid and watery, with poor quality and less nutritive values (Syamal et al., 1980). Singh et al., (1991) studied the various cropping pattern and recommended a single winter crop in one year in order to harvest a highly economical crop of the best quality fruits.

Several methods have been tried to induce new vegetative growth during rainy season so that bumper crop is obtained in subsequent winter season (Shigeura and Bullock, 1976, Singh et al., 2000). Coordination of the fruiting cycle can help in maintaining fruit supplies during most months (Lopez etal., 1982, Manica et al., 1982, Lopez and Perez, 1977and Shatat, 1993). Guava fruit harvest peaks can deviate with prevailing weather conditions and cultural practices because flowers are produced on new growth.
Irrigation (Singh et al., 1997), fertilization (Shigeura and Bullock, 1976), defoliation and pruning (Singh et al., 1996, Shigeura and Bullock, 1976, Shatat, 1993) can be usedto stimulate new growth and influence fruiting in guava. Several workers have reported increased yield, fruit size and qualitative attributes of guava as a result of pruning at different periods. Cassin et al., (1969) reported that unrestricted growth gives rise to more vegetative growth than the reproductive growth, as temperature or moisture stress is essential for flowering. Regulated crops are desired to avoid the glut in the market and ensure the regular supply of fruits. Nir et al., (1972) reported that increased intensity of flowering due to stress showed that flower differentiation occurred during moisture stress and that generative buds formed did not undergo flower development till water was supplied. Goell et al., (1981) reported that moisture stress followed by alleviation was effective in initiating and promoting vegetative flushing. The flowering is delayed under longer period of stress which may be due to conditions like high and low temperature and low humidity condition. Singh and Chadha (1988) advocated that imposition of stress caused uniformity in flushing and intensity depended on amount of stress as measured by relative water content (RWC) in plant before alleviation.

\section{Why crop regulation}

Many crops which bloom more than one in a year do not produce good yield and quality of the fruit throughout the year. The yield and quality depends on the bahar. For example, the rainy season crop of guava is poor in quality and crop is affected by many biotic and abiotic stresses as compared to winter season crop. The winter season crops (mrigbahar) which ripen from second fortnight of October to first fortnight of January are superior in quality, free from 
diseases and pests and fetch higher income. This requires regulation of flowering (from ambebahar to mrigbahar) to obtain most profitable crop by several methods. In different regions various methods of crop regulations are followed depending on climatic factors, cropping pattern, cultivar etc. The flowering is more in guava during summer season because of heavy new flushes that lead to more fruit production in rainy season. In this season, duration of fruit harvesting is reduced to 30 days due to high temperature and rainfall and it causes glut in the market which lead to poor price and less demand in the market. Winter season crop is superior in quality which fetches higher prices than rainy season crop. In rainy season there is a serious attack of fruit flies which deteriorates its quality and fruits become unfit for human consumption. So far getting the quality fruits in guava only winter season crop should be taken and rainy season crop should be avoided. Water availability is big issue in Maharasthra, Rajsthan and Gujrat during summer season for pomegranate grower. They always avoid taking ambebahar crop and regulating this crop in to mrigbahar with the onset of monsoon and crop is harvested during winter and some farmers prefer hasthbahar with less availability of water.

\section{Crop Regulation in different crops}

Guava is most important commercial fruit crop grown in sub-tropical region of the Indian subcontinent. It gives an assured crop with very little care. Its cost of production is also low as compared to most of other commercial fruit crops. In guava, two distinct seasons of flowering, spring (March-April) and rains (June-July) occur from which fruits ripen during rainy and winter season respectively. In North Indian climate the rainy season crop of guava is poor in quality and nutritive value and is affected by many insect pests and diseases. The winter season fruits are superior in quality free from diseases and pests and give higher income. But it is advisable to take only one crop every year. This requires management of flowering to obtain the most desirable crop, by the methods like withholding irrigation, pruning, thinning of flowers by chemically or manually. In guava, mainly mrigbahar flowering is preferred by grower and fruits are harvested during winter season. This season crop is free from insect pest and diseases, and produces good quality fruits.

Pomegranate flowers continuously when watered regularly. The plants under such conditions may continue bearing flowers and bear small crop irregularly at different period of the year, which may not be desirable commercially. To avoid this trees are given bahar treatment. In this treatment, the irrigation is withheld two months prior to the bahar followed by light earthing up in the basin. This facilitates the shedding of leaves. The trees are then medium pruned 40-45 days after withholding irrigation. The recommended doses of fertilizers are applied immediately after pruning and irrigation is resumed. This leads to profuse flowering and fruiting. The fruits are ready for harvest 4-5 months after flowering. In tropical condition, there are three flowering seasons, viz., January-February (ambebahar) June-July (mrigbahar) and September-October (hasta bahar). The choice of flowering/fruiting is regulated taking into consideration the availability of irrigation water, market demand and pest/disease incidence in a given locality. The fruits of ambebahar are ready for harvest in the month of June to September. As the fruit development takes place during dry months, they develop an attractive colour and quality thus suitable for exports. Similarly due to dry weather, the incidences of pest and disease attack are limited. However, ambebahar can be taken only areas having assured irrigation facilities. Themrigbahar 
crop is harvested in the month of December to February. Usually this bahar is favoured as the flowering and fruiting period coincides with rainy season or immediately after rains, and the crop is taken without much irrigation. As the fruits develop during the rainy season and mature during winter, the colour and sweetness of the fruit is affected. The fruits from hasta bahar are harvested during the month of March to April. They have very attractive rind with dark coloured arils. Since the availability of the fruits during this season is limited, they fetch high value. Optimum water stress cannot be developed during this period as withholding of irrigation coincides with the rainy season. This leads to poor flowering and thus affects the yield.

The lemon, lime and citron are considered as continuous bloomers, particularly under tropical climate producing some flowers throughout the year, though the spring bloom is the heaviest. The acid limes bloom throughout the year but the main blooming period is February - March, with lean period from July to August. Acid lime in tropical and sub-tropical conditions tends to give continuous flushes of growth, both vegetative as well as reproductive throughout the year. Acid lime trees flower thrice in a year in the months of January- February, June- July and September-October known as Ambe, Mrig and Hasta bahar, respectively. The fruits of the Ambe, Mri and Hasta bahar flowering becomes available in the month of June-July, November-December and April-May months, respectively. The flowering percentage of Ambe, Mrig and Hasthbahar occurs $47 \%, 36$ $\%$ and $17 \%$, respectively. The fruits of Hasthbahar flowering become available in the months of April-May when there is heavy demand and is sold at premium price. But Hasta bahar (summer cropping) bear only 17 $\%$ flowering and fruiting is achieved in the uncontrolled condition because of the monsoon rains preceding flower initiation.
Therefore, acid lime is forced to produces hasthbahar crop. Use of Gibberellic acid $\left(\mathrm{GA}_{3}\right)$ during stress period is known to reduce the intensity of flowering in the following flowering season. Cycocel (CCC) has been found very effective for imposing stress for inducing flowering. $\mathrm{GA}_{3}(50 \mathrm{ppm})$ increased yield and quality of Allahabad safeda guava in Assam condition (Lal and Das, 2017). Potassium nitrate $\left(\mathrm{KNO}_{3}\right)$ chemical for sprouting has been found effective in acid lime. The water stress with harmones played an important role in regulation of flowering and there is relationship between severity of stress and flowering response (South Wick and Davenport, 1987; Barbera and Garimi, 1988). Webner (1943) observed that the time of flowering is reported to vary with temperature. Flowering was about a month earlier in higher temperature zone (Florida) than in cooler temperature zone (California). Motial (1964) reported that kagzi lime flowered only once a year under Saharanpur conditions. Hittalmani (1977) reported that the maximum flowering occurred only during December-January and May-July periods. Flowering potential is more related to the season than the age of the shoot. The magnitude of fruit setting and retention was however, higher in June flowering than in January. It was further revealed that, flowering was related to the season rather than to the physiological age of the shoots. $C$. aurantifolia bore flowers mainly on lateral shoots, whereas $C$. latifolia flowered mainly on terminal shoots (Hittalmaniet al., 1977). Rohidas and Chakrawar (1989) studied the ambebahar flowering under Parbhani, Maharashtra, India condition and reported that flowering started asearly as in November and continued till February with aduration of 50 to 55 days and peak between 15 to 31 January. Athani et al., (1998) noticed that the flowering was twice in Karnataka - once during December - January and again during July - August. Ghawede et al., (2002) 
revealed that in Akola, India, there were only two main flowering seasons, the first and the major one occurring in December - February (Ambebahar) constituting more than $50 \%$ of total number of flowers produced in the year and second one in June - July (MrigBahar)constituting about 25\% of total number of flowers. Majority of the shoots which bore flowers were normal invigour as measured in terms of length of shoot and flowers were mostly on lateral shoots (> 80\%) and in the apical region of shoots. In central India, mandarins bloom thrice a year. Under such circumstances, plants give irregular and small crops at indefinite intervals. To overcome this problem and to get fruitful yield in any of the three flowering seasons', flowering is regulated in such a way that we could get only crop which will be beneficial to the grower and selection of bahar depends on the climatic condition and availability of water.

\section{Principle of crop regulation}

The basic principle of crop regulation is to manipulates the natural flowering of the guava plant in desired season that contribute to increased fruit yield, quality and profitability. This concept is based on the fact that most of the crops' flowers are borne only on new, succulent, vigorously emerging vegetative growths. These new growth flushes can be either on new emergences of lateral bud on older stems or extensions of already established terminals of various size and vigour.

\section{Objectives of crop regulation}

The main objective of crop regulation is to force the tree for rest and produce profuse blossom and fruits during any one of the two or three flushes. To regulate a uniform and good quality of fruits and to maximize the production as well as profit to the grower.
To reduce cost of cultivation because uninterrupted continuous blossom would produce light crops over the whole year and require a high cost for the monitering and marketing.

\section{The selection of bahar at a location is mainly determined by}

Availability of the irrigation water

Quality of products

Occurrence and extend of the damage by the disease and pests

Market demands

Climate of the area

Availability of fruit in the market

Comparable yields

\section{Methods of crop regulation}

In order to get only appropriate season crop it is necessary to manipulate the flowering. The following practices can be adopted:

Deblossoming or Thinning

Withholding of irrigation

Root exposure and root pruning

Shoot Pruning

Chemical/PGRs application

Nutrients application

Shoot bending

\section{Deblossoming or Thinning}

Different chemicals caused deblossoming in rainy season crop and subsequently increased the winter season crop (Singh et al., 1990 and 1991 and 1996a and Singh and Reddy, 1997). Rathore (1975) noted 96 per cent deblossoming with 100 ppm NAA in guava. While Chundawat et al., (1975) reported 24, 51 and 82 per cent deblossoming with 100 , 200 and 400 ppm NAA spray, respectively. Complete deblossoming has been recorded by Pandey et al., (1980) obtained complete deblossoming with 400 ppm of NAA guava. 
However, Singh et al., (1991) reported complete deblossoming with $1800 \mathrm{ppm}$ ethephon followed by 1 and 2 per cent potassium iodide followed by 15 to 20 per cent urea and $1800 \mathrm{ppm}$ ethephon especially at higher concentrations. Whereas, Kaur (1997) found maximum abscission of flowers by the spray of 0.5 per cent potassium iodide followed by 20 per cent urea. Maximum deblossoming has been observed with 20 per cent urea spray in guava (Dwivedi et al., 1990 and Singh et al.,; 1996a).Whereas, Singh et al., (1994) and Choudhary et al., (1997) found 15 per cent urea most effective in deblossoming the rainy season guava crop. However, Singh and Singh (1994) reported complete deblossoming with double spray of 15 per cent urea in guava to regulate the crop. Similar findings were reported by Singh et al., (1993) that deblossoming can be carried out by Spray 10 per cent urea or naphthalene acetic acid (NAA) @ 600 ppm of water during the month of May, when maximum flowers have opened. Each tree requires about 10-12 liters of solution i.e. about 1000 liters per acre. For preparing NAA solution, dissolve $600 \mathrm{~g}$ of NAA in 1500-2000 ml alcohol, then make the volume of 1000 liters. Deblossoming can also be done manually. By deblossoming or thinning in April May flowers, the trees become work potential to produce profuse flowering in June- July and fruit harvesting in the month of November to February.

Growth regulators and certain chemicals have been found very effective in thinning of flowers and manipulating the cropping season NAA, NAD, 2, 4-D carbaryl and ethrel were found successful in reducing the rainy season and increasing the winter crop under different agroclimatic conditions (Chundawat et al., 1975). Manual deblossoming of rainy season flowers at small scale, kitchen garden and early age of the plant is very effective, but at large commercial plantation it is not in practice which is very cumbersome, laborious and uneconomic. Flower thinning by using naphthalene acetic acid (NAA), naphthalene acetamide (NAD), 2,4-dichlorophenoxy acetic acid (2,4-D),potassium iodide (KI), 2chloroethyl phosphonic acid (ethephon), 4,6dinitro-o-cresol (DNOC) and urea have been tried with varying degree of success. This variation may be due to cultivars, tree condition, soil type and environment. Most of the workers are in opinion that chemical thinning is economic and it increases the winter yield as well as improves fruit quality. It was, however, found that hand thinning was effective in reducing the number of fruits in rainy season crop with the subsequent increase in winter crop. The maximum reduction in number of fruits during rainy season by manual removal of flowers closely followed by pruning which subsequently produced more fruits per tree in the following winter. According to Sing et al., (1996), flower thinning from guava plants during summer, improved fruit quality and increase yield during next winter

\section{Withholding of irrigation}

In northern plains withholding irrigation after harvesting of winter crop of guava, results in the shedding of flowers and the tree goes to rest. The well balance manure and fertilizer along with irrigation is applied June. After about 20-25 days the tree put forth profuse flowering and fruit mature in winter. Induction of water stress by withholding irrigation from December to June or until the beginning of monsoon depending upon the prevailing conditions has been recommended (Cheema et al., 1954)

\section{Root exposure and root pruning}

Roots of the plant are exposed to sun by removing up to $7-10 \mathrm{~cm}$ soil around 40-60 $\mathrm{cm}$ radius of tree trunk. The water is withheld 
for a month or two before flowering. As a result of water stress, leaves show wilting and fall on the ground. Before one month of commence of flowering of desired bahar, roots are again covered with a mixture of soil and FYM and irrigated immediately. Subsequent irrigations are given at suitable intervals. Consequently, plants give new vegetative growth, profuse flowering and fruiting. However, in light sandy and shallow soils, exposure of roots should not be practiced and mere withholding of water for 2-3 weeks is sufficient for wilting and debilitation of trees. It depends upon the choice of the grower as to which of the three bahars is to be taken to get maximum profit. As the availability of water is a problem in central India during April - May, the farmers prefer mrigbahar (June) so that the plants are forced to rest in April - May and no water is required during the period. Plants put forth new vegetative growth, followed by flowering (July- August) and fruiting during the coming season. Resting treatment is not feasible in North India, as mandarin plants normally rest in winter and flower once a year. Cheema et al., (1954) reported that root exposure and root pruning can be used to suppress the rainy season crop so as to get a good winter crop in guava. In certain parts of Maharashtra, root pruning is practiced to produce heavy yield. The roots are exposed and minute roots are cut away and irrigation is withheld so as to allow the leaves to shed in guava (Kumar, 2010).

\section{Shoot pruning}

Terminal portion of the guava up to 20 or 30 $\mathrm{cm}$ length should be pruned during April to avoid Ambebahar and always avoid severe pruning. Pruning the current season's growth of spring flush to avoid the rainy season crop was advocated. Pruning current season's growth of spring flush to avoid rainy season crop has been advocated in northern parts of the country. The pruning of $25-50 \%$ shoots on 20 April, 10 May or 30 May was found to escape flowering in rainy season and encouraged winter season flowering of Sardar guava. Pruning the tender's shoots by about 4 to 5 inch from their tips decreased the flower drop percentage in guava trees (Arivindakshan, 1963) during rainy season. Similar observations were also made by Bajpai et al., (1977). The minimum flower drop was recorded on severely pruned trees $(100 \mathrm{~cm})$ and miximum flower drop was obtained on lightly pruned trees $(30 \mathrm{~cm})$ of guava during the rainy season (Bajpai et al., 1973). Whereas, Tiwari et al., (1992) reported the increased flowers growth through pruning but in the following winter season flower drop percentage decreased. But contrary to this, Lal et al., (1996) found that as the pruning intensity increased the flower drop percentage decreased in the rainy season. Singh and Bal (2006) reported that pruning help in reducing the tree size and improving the fruit quality. Lal (1983) reported that pruning increases yield of guava. Pruning and hydrogen Cyanamid were found to modify the production curve of guava (Quijada et al., 1999). Salah (2005) reported that pruning produced the highest bud emergence in guava. The time and intensity of pruning affected guava cv. Paluma tree sprout and yield (Serrano et al., 2008a).Moreover, (Serrano et $a l ., 2008 b)$ reported that the light pruning increased the number of productive branches and number of fruits per branch of Guava cv. paluma.

\section{Chemical/PGRs application}

Desai et al., (1982) from Rahuri, Maharashtra, India revealed that cycocel sprayed at $1000 \mathrm{ppm}$ once on $16^{\text {th }}$ August and once on $16^{\text {th }}$ September to be followed by spray of $2,4,5-\mathrm{T}$ at $10 \mathrm{ppm}$ on $30^{\text {th }}$ September resulted in 58.2 percent flowers as against 16.3 percent in control. Increase in the number of flowers and fruits with every 
increase in the concentration of the chemical were also evident. Babu and Rajput (1982) noted that February and June flowering was earliest with 2, 4-D at 10 or $20 \mathrm{ppm}$ and latest with $\mathrm{GA}_{3}$ at 25 or $50 \mathrm{ppm}$. Duration of flowering was shortest (22 - 24 days) with $\mathrm{GA}_{3}$ at $50 \mathrm{ppm}$ and longest in the controls (30 - 35 days) whereas Davenport (1983) reported that $\mathrm{GA}_{3}$ applied to Tahiti lime (Citrus latifolia Tan.) markedly inhibited flowering, producing morphologically typical vegetative growth. Babu and Rajput (1984) at Varanasi showed that Zinc alone or in combination with either of the growth regulators had a marked influence on the chlorophyll content of the leaves. $\mathrm{GA}_{3}$ alone reduced the chlorophyll contents while 2, 4-D had no effect. Tripathi and Dhakal (2005) reported that paclobutrazol applied on $17^{\text {th }}$ July was the most effective in inducing early flowering at fourth week of December which was 70 days ahead of normal flowering days. The subsequent application on September, October and December also advanced flowering time by 59,41 and 32 days respectively. The earliest (July) application of paclobutrazol was superior among the treatments under Chitwan, Nepal condition to induce and advance early flowering for off season market. Thirugnanavel et al., (2007) revealed that application of $\mathrm{GA}_{3}$ $50 \mathrm{ppm}$ in June + cycocel $1000 \mathrm{ppm}$ in September $+\mathrm{KNO}_{3} 2 \%$ in October showed better performance in delaying flowering by nearly two months, number of flowers per shoot (7.01), initial fruit set (4.59), fruit retention (3.21 fruit per shoof) number of fruits/tree (224 fruits) and yield (11.15 kg). Mahalle et al., (2010) reported in Hasta bahar flowering (i e., September and October) of Acid lime, two sprays of cycocel $1000 \mathrm{ppm}$ at an interval of one month before initiation of flowering that is in August and September resulted in maximum yield in terms of number of fruits per tree and weight of fruits per tree and this treatment also improved the fruit quality in respect to juice \%, TSS, acidity, ascorbic acid content, peel and pomace per centage. The onset of flowering in acid lime may be attributed to the prolonged rest period which is often associated with cool, sub-tropical winter or water stress conditions in the tropics. The cessation of root growth as a result of low temperature, water stress, weak rootstocks and confined roots were necessary for floral induction. This was later explained that based on the flower inhibitory effects of exogenously applied $\mathrm{GA}_{3}$, the citrus buds are continually induced to flower but inhibited from doing so by the presence of endogenous, root produced gibberellins. Conditions conducive to inhibition of root growth would, thus reduce the levels of gibberellins distributed to buds resulting in expression of the depressed flowering buds. This proposal was proved by many workers as above. The flowering intensity increases due to stress and flower differentiation occurs during moisture stress and the generative buds formed do not undergo flower development till water is supplied. Preconditioning of plant by moisture stress is a prerequisite in acid lime flower formation. Carbohydrate accumulates during stress and GA availability is reduced due to restricted root growth. On watering GA level rises which is needed for generative branches resulting in flowering. Paclobutrazol inhibits the biosynthesis of GA and internode elongation which reduces the availability of GA. Bromouracil, 2, $4 \mathrm{D}$ and paclobutrazol in variable doses are effective in inducing flowering in acid lime.

\section{Nutrition application}

To increase the quantum of winter crop the fertilizer schedule should be changed from April-May to May-June that will induce more vegetative growth that subsequently increases the winter cropping (Boora et al., 2016). Gupta and Nijjar (1978) advocated that application of a combination of NPK@ 40,100, $40 \mathrm{~g}$, respectively. Singh and Singh, 1994 recommended that $10 \%$ urea for better crop of Sardar guava and Allahabad safeda during winter under Lucknow and Punjab condition.

\section{Bending of shoot}

Shoot bending is one of the ways to produce 
better quality fruits in the off-season of guava (Sarker et al., 2005). In case of bending of branch wood tension of branch is increased and phloem formation decreased. As a result photosynthetic product pass slowly from the shoots of bent branch as to the other parts, maintaining increased $\mathrm{C}: \mathrm{N}$ ratio and induce more flowering and fruit set. Bending forced dormant reproductive buds into growth. The upright branch produces fewer flowers and fruits than the bent branch (Ito et al., 1999). Bending induces profuse flowering and fruiting, as well as fetches greater returns (Ghosh, 2003) and regulate flowering by bending of shoots (Mitra, et al., 2008). Bending consistently increased the lipid, tryptophan, proline, polyphenol oxidase, catalase, and peroxidase levels in leaves, bark, and fruits, but decreased phenolics (Eassa et al., 2012). These changes may have resulted in greater flowering and fruiting, giving rise to higher yield (Praagh and Hauschildt 1991on apple and pear; Sarkar, et al., 2005 and Bagchi et al., 2008 on guava). Mamum et al., (2012) found that the highest number of flowers set per plant when shoot bending treatment was given during on-season (312.33) and off-season it was (111.33). The shoot bending treatment result the highest number of fruits set per plant both on and off season (246.86) and (67.33), respectively. Shoot bending increased the fruits set per plant during off-season is also reported by Sarker and Ghosh (2006). Shoot bending increased the fruit yield per plant and quality fruit during off-season (Sarker et al., 2005). Samant et al., (2016) has also shown the positive effect of shoot bending in guava. Branch bending was done during May by retaining 10-15 pairs of leaves at apex and removing all the leaves, flowers and developing fruits manually. Branches were bent dawn by applying pressure gradually from proximal to distal end of branch. They were kept at bent position by tying the tip of branches to the wooden pegs fixed on the ground with the help of rope till flushing completes i.e. for 40-45 days. They concluded that branch bending had shown positive influence on shoot growth, flowering intensity, yield and fruit quality.

\section{References}

Aravindakshan, M. 1963. Effect of pruning on growth, flowering and fruit set in guava.Madras Agric. J. 50: 87

Athani, S.I., Hulamani, N.C. and Patil, M.P. 1998. Flowering and fruit set behaviour of kagzi lime strains. Adv. Agric. Res., 9: 151-53.

Babu, R. S.H. and Rajput, C. B. S. 1984.Effect of $\mathrm{Zn}, 2,4-\mathrm{D}$ and $\mathrm{GA}_{3}$ on the chlorophyll content of acid lime leaves. South Indian Hort., 32: 365-66.

Babu, R.S.H. and Rajput, C.B.S. 1982.Effect of Zinc, 2, 4-D and $\mathrm{GA}_{3}$ on flowering in Kagzilime. Punjab Hort. J., 22: 140-44.

Bagchi, T.B., Sukul, P. and Ghosh, B. 2008. Biochemical changes during off-season flowering in guava induced by bending and pruning. Journal of Tropical Agriculture, 46 (1/2): 64-66.

Bajpai, P.N, Mohan, A., Shukla, H.S. and Dwivedi, R.M.1977. Response of guava suckers to pruning. Plant Sci., 9: 65-66.

Bajpai, P.N. Shukla, H.S. and Chaturvedi, A.M. 1973. Effect of pruning on growth, yield and quality of guava, Allahabad Safeda. Prog. Hort., 5: 73.

Barbera, G. and Garimi, F. 1988. Sixth Intern. Citrus Congress Middle East Telavive Israel, 8 - 11 March. 88: 2.

Boora, R.S, Dhaliwal, H.S. and Arora, N.K.2016.Crop regulation in guava-A review, Agricultural Reviews, 37 (1): 1-9

Cassin, J., Bourdeaut, J., Fourgerl, A., Furon, V., Gillard, J.P., Montagut, G. and Morevilli, C. 1969. The influence of climate upon the blooming of citrus in tropical area. Proc. Int. Citrus Symp, 1: 315-23.

Cheema, G.S., Bhatt, S.S. and Naik, K.C. 1954. Guava In Commercial Fruits of India. Macmillan \& Co. Ltd Calcutta.

Choudhary, R., Singh, U.P. and Sharma R.K. 1997.Deblossoming of rainy season crop of guava. Horticultural J., 10: 93-95.

Chundawat, B.S., Gupta, O.P. and Godara, N.R. 1975. Crop regulation in BanarsiSurkha 
guava cultivar.Haryana J. Hort. Sci., 4: 23.

Davenport, T.L. 1983. Daminozide and Gibberellin effects on floral induction of Citrus latifolia. Hort. Sci., 18: 947-49.

Desai, U. Choudhari, K. G., Rane, S. D. and Patil, Y. S. 1982.Alteration of flowering period in kagzi lime with plant growth substances. J.Maharashtra Agric. Univ., 7: 161-62.

Dwivedi, R., Pathak, R.K. and Pandey, S.D. 1990.Effect of various concentrations of urea on crop regulation in guava (Psidium guajava L.) cultivar Sardar.Prog. Hort., 22: 134-139.

Eassa, K. B.,Gowda, A. M.and El-Taweel, A. A. 2012.Effect of $\mathrm{GA}_{3}$, hand pollination and branch-bending on productivity and quality of banati guava trees grown in sandy soils. J. Plant Production, Mansoura Univ., 3 (2): 241 - 251.

Ghawade, S.M., Panchbhai, D.M., Jadhao, B.J., Katole, S.R. and Dadmal, S.M. 2002. Flowering behaviour of kagzi lime (Citrus aurantifolia Swingle) under subhumid tropical climate. Agric. Sci. Digest., 22: 252-54.

Ghosh, B. 2003.Progress report of NATP on "Off-season flower of guava". Faculty of Horticulture, BCKV, Mohonpur, Nadia, W.B., pp 3-5.

Goell, A., Golgmb, Kalmar, D., Montell, A. and Sharon, S. 1981. Moisture stress a potent factor for affecting vegetative growth and tree size on citrus. Proc. Int. Soc. Citri Cult., 2: 503-06.

Gupta, M. R. and Nijjar, G. S. 1978.Crop regulation in guava.Indian J. Hort., 35: 23-27.

Hittalmani, S. V. 1977. Studies on growth and fruiting in kagzi (Citrus aurantifolia Swingle) and Tahiti (Citrus latifolia Tanaka) limes.MysoreJ.Agric. Sci., 11: 113.

Hittalmani, S. V., Rao, M. M. and Bojappa, K. M. 1977.Studies on the parameters of flowering in the kagzi and Tahiti limes in North Kamataka.Punjab Hort. J., 17: $97-$ 03 .
Ito, A., Yaegaki, H., Hayama, H., Kusaba, S., Yamaguchi, I. and Yoshioka, H. 1999. Bending shoots stimulates flowering and influences hormone levels in lateral buds of Japanese pear. Hort. Sci., 34, 12241228.

Kaur, N. (1997). Crop regulation in Sardar guava by chemicals. M.Sc. thesis submitted to Punjab Agric Univ., Ludhiana.

Kumar, N. 2010.Introduction to horticulture. Oxford \& IBH publishing co.pvt. Ltd, New Delhi

Lal, N. and Das, R.P. 2017. Effect of Plant Growth Regulators on Yield and Quality of Guava (Psidium guajava L.) cv. Allahabad Safeda. Int.J.Curr.Microbiol.App. Sci., 6(5): 857863

Lal, N., Das, R.P. and Verma, L.R. 2013.Effect of plant growth regulators on flowering and fruit growth of guava (Psidium guajava L.) cv. Allahabad Safeda. The Asian Journal of Horticulture, 8(1): 5456.

Lal, S.1983. Effect of pruning on crop regulation in guava (Psidium guajava L.) cv. Lucknow-49.Prog. Hort., 7(3): 60-62

Lal. S, Tiwari, J.P and Misra, K.K. 1996.Effect of plant spacing and pruning intensity on flowering and fruiting of guava. Ann. Agric. Res., 17: 83-89.

Lopez, G.J. and Perez, R.P. 1977. Effect of pruning and harvesting methods on guava fields. J. Agri. Puerto Rico, 61:143-51.

Lopez, J.G.V., Manica, I., Koller, O.C. andRibold, I.J. 1982.Effect of six pruning periods on the yield of guava in Novo Hamburgo, Rio $\mathrm{G}$ randedoScl, Brazil. Proc. Trop. Reg. Am. Soc. Hort. Sci., 25:259- 62.

Mahalle, S.S., Ingle, H.V. and Sable, P.B. 2010. Influence of plant growth regulators and chemicals on yield and quality of Hasta bahar in Acid lime. Green Farm, 1: 28587.

Mamun, A.A., Rahman, and Rahim, M. A. 2012. Effect of Shoot Bending and Fruit Thinning on Productivity of Guava. $J$. 
Environ. Sci. \& Natural Resources, 5(2): $167-172$.

Manica, I., Passos, L.P., Mundstock, E.C., Chaves, J.B. and Stringheta, P.C. 1982. Effect of four times of pruning on the production of two guava varieties in Minas Gerais, Brazil. Proc. Trop. Reg.Am. Soc. Hort. Sci., 25:259-61.

Mitra, S. K.,Gurung, M. R. and Pathak, P. K. 2008. Sustainable guava production in West Bengal, India. Acta Horticulturae. 2008. 773, 179-182.

Motial, V.S. 1964. Fruit set and fruit drop studies in some non-commercial citrus fruits. Punjab Hort. J., 4: 27- 33.

Nir, I., Goress, R. and Leshem, B. 1972.Effect of water stress, gibberellic acid and 2chloroethyl trimethyl ammonium chloride (CCC) on flower differentiation in Eureka lemon trees. Amer.Soc. Hort. Sci., 97: 774-78.

Pandey, R.M., Lal, S. and Kaul, G.L. 1980. Effect of chemicals and flower thinning on regulation of crop in guava. Indian $J$. Hort., 37: 234.

Praagh, J.P. and Hauschildt, H. 1991.Evaluation of shoot-bending, pruning and pollination for increasing fruit-set and yield on young "Cox" trees. Acta Horticulturae. 1991. 288, 244-248.

Quijada, O, Araujo, F. andCorzo, P. 1999. Effect of pruning and hydrogen cyanamide on bud break, flowering, fruit yield and quality of guava (Psidium guajava L.) in the municipality of Mara, state of Zulia. Revista de la FacultaddeAgronomia, Universidad Del Zulia., 16(3): 276-291.

Rajput, C. B. S. and Babu, R. S. H. 1985.Citriculture. Kalyani publishers, New Delhi. pp. 37.

Rathore, D. S. 1975. Deblossoming of rainy season crop of guava by NAA. Prog. Hort., 7: 63-65.

Rathore, D.S. and R.N. Singh, 1974.Flowering and fruiting in three cropping pattern of guava. Indian J. Hort., 34:331-36.

Rawal, R.D. and Ullasa, B.A. 1988. Management of fruit diseases of guava
Psidium guajava L. Through fungicidal sprays. Indian J.Agric. Sci., 58:950-52.

Rohidas, S. B. and Chakrawar, V. R. 1989. Studies on floral biology of some important citrus species. II Kagzi lime (Citrus aurantifolia Swingle) Hort. J., 2: 20-25.

Salah, A. El-D.M. 2005. Effect of pruning on growth, flowering and fruiting of some guava cultivars. M.Sc. Thesis, Fac. Agric. Cairo Univ.

Samant, D., Kishore, K. and Singh, H.S. 2016.Branch Bending for Crop Regulation in Guava under Hot and Humid Climate of Eastern India. J. Indian Soc. Coastal agric. Res., 34(1): 92-96.

Sarkar, A., Ghosh, B. Kundu, S. and Sukul, P. 2005. Effect of shoot pruning and bending on yield and fruit quality in guava cv. L-49. Environment and Ecology, 23S: Special 3: 621-623.

Sarker, A. and Ghosh, B. 2006. Studies on growth, yield and economics in guava cv. L-9 by shoot pruning and bending. $J$. Interacdemicia, 10(3): 327-330.

Serrano, L.A.L, Marinho, C.S., Gabetto, E., Silva, M. and Tardin, F.D. 2008a. Phenological and yield characteristics of "Paluma" guava tree pruned in different times and intensities, in north of Rio de Janeiro State, Brazil. Revista Ceres, 55(5): 416-424.

Serrano, L.A.L, Martins, M.V.V. De, I. Lima, M. Marinho, C.S. and Tardin, F.D. 2008b.Effect of pruning time and intensity on Paluma' guava trees, in Pinheiros, ES, Brazil. Revista Brasileira de Fruticultura, 30(4): 994-1000.

Shatat, F.A. 1993. Pruning guava (Psidium guajava L.) effect of pruning date on yield and quality. Dirasat (Series B, Pure and applied Sci.), 19:153-59.

Shigeura, G.T. and Bullock, R.M. 1976. Management of guava: Cycling fruit set for continuous production. Proc. Trop. Ref. Am Soc. Hort.Sci., 24:166.

Singh, A. K., Gorakh, S., Pandey, D., Rajan, S. and Singh, G. 1996. Effect of cropping pattern on quality attributes of guava 
(Psidium guajava) fruits. Indian J. Agric. Sci., 66 (6): 348-352.

Singh, G., and Reddy, Y.T.N. 1997. Regulation of Cropping in guava. Indian J. Hort., 54: 44-49.

Singh, G., Pandey, D., Rajan, S. and Singh, A.K. 1996a.Crop regulation in guava through different crop regulating treatments.Fruit (Paris), 51: 241-246.

Singh, G., Rajan, S. and Pandey, D. 1990.Standardization of Agro-techniques for guava. Annual Report, CIHNP: 11-14, Lucknow.

Singh, G., Rajan, S. and Pandey, D. 1991.Standardization of Agro-techniques for guava. Annual Report, CIHNP: 14-18, Lucknow.

Singh, G., Rajan, S., Pandey, D. and Singh, A.K. 1997. Effect of soil moisture stress on water relation by plant and cropping behaviour in guava (Psidium guajava L.). Indian J. Agric. Sci., 67:303-06.

Singh, G. and Singh, A.K. 1994. Urea induced defoliation and subsequent yield in guava. Fertilizer News, 39: 39- 41.

Singh, G., Singh, A.K. andPandey, D. 2000. Effect of cropping pattern on fruiting behaviour of guava (Psidium guajava L.).Tree Am. Agric. Res, 22:175-82.

Singh, H. and Bal, J. S. 2006. Effect of pruning and growth regulators on physio-chemical characters of guava during rainy season planted at different spacing. Internat. J. agric. Sci., 2 (2): 533-537.

Singh, H. P. and Chadha, K. L. 1988.Regulation of flushing and flowering in acid lime (Citrus aurantifolia Swingle) through stress management. Prog. Hort., 20: 1-6.

Singh, H., Mehrotra, N.K. and Shergill, T.S. 1994. Effect of urea spray on the crop regulation of guava cv. Allahabad Safeda.Indian J. Hort. 51:331-36.

Singh, U.P., Sharma, R.K. and Hoda, M.N. 1993. Regulation of cropping in guava. The Hort, J. 6: 1-6.

Singh, V. 1985.Effect of foliar spray of urea on growth yield and quality of guava. Udyanika, 5:11-16.

South Wick, S.M. and Davenport, T.L. 1987.Proc. of plant growth regulator. Soc. of Amer., 487-488

Syamal, M.M., Singh R.K. and Chhlonkar, V.S. 1980. Studies on growth and flowering in guava, Psidium friedrichsthalianum, 37:243-45

Thirugnanavel, A., Amutha, R., Rani, W. B., Indira, K., Mareeswari, P., Muthulaksmi, S., Parthiban, S. 2007. Studies on regulation of flowering in Acid lime (Citrus aurantifolia Swingle). Res. J.Agril. Biol. Sci., 3: 239-41.

Tiwari, R. B.; Tiwari J.P and Lal, S. 1992. Effect of shoot pruning, NAA and urea on cropping pattern of guava. Indian $J$. Hort., 49: 305-308.

Tripathi, K. M. and Dhakal, D. D. 2005.Effect of paclobutrazol on off-season flower induction in acid lime (Citrus aurantifolia, Swingle) land races under Chitwan condition. J. Inst. Agric.Anim. Sci., 26: 87-92.

Webber, H. J. 1943.Plant characteristics and climatology. The Citrus Industry, California, 1: 41-47.

\section{How to cite this article:}

Narayan Lal, Nisha Sahu, E.S. Marboh, A.K. Gupta and Patel, R.K. 2017. A Review on Crop Regulation in Fruit Crops. Int.J.Curr.Microbiol.App.Sci. 6(7): 4032-4043. doi: https://doi.org/10.20546/ijcmas.2017.607.418 